\title{
RHIZOPHIDIUM POLYSIPHONIAE IN THE UNITED STATES
}

CONTRIBUTIONS FROM THE HULL BOTANICAL LABORATORY 292

GEORGE W. MARTIN

(WITH TEN FIGURES)

The morphology and distribution of the fungi parasitizing marine plants are still so imperfectly known that additional facts concerning any of them seem worth placing on record. Among some algal material collected by Dr. T. C. NeLson in Barnegat Bay, New Jersey, and sent by him to the writer preserved in formalin, occurred a small sterile plant of Callithamnion which was observed to bear numerous sporangia of a chytridiaceous fungus. The mature sporangia were globose or nearly so, from 22 to $39 \mu$ in diameter, averaging $33 \mu$, and closely appressed to the attacked host cell, which could be sharply distinguished from the neighboring unattacked cells by the partial or nearly complete exhaustion and decoloration of its contents. In only one instance was more than one sporangium attached to a single host cell (fig. 8). The cell contents are destroyed first at the end at which the fungus is attached (fig. 3), and by the time the sporangium becomes mature the contents of the parasitized cell are, as a rule, almost exhausted (figs. I, 2, 6, 8). In some cases a branched, rootlike mycelium, rather coarse for this genus, could be seen within the host cell and traced to the base of the sporangium (figs. I, 2, 8, 9, го). More frequently the mycelium could not be distinguished. The zoospores are from 2 to $3 \mu$ in diameter, globose or somewhat irregular in shape, and are evidently liberated through an opening developed from a papilla, of which each sporangium bears from one to several (figs. I, 4, 5). Each zoospore contains a nucleus or oil globule, and in addition a much smaller body, observed only in the spores remaining in a nearly 

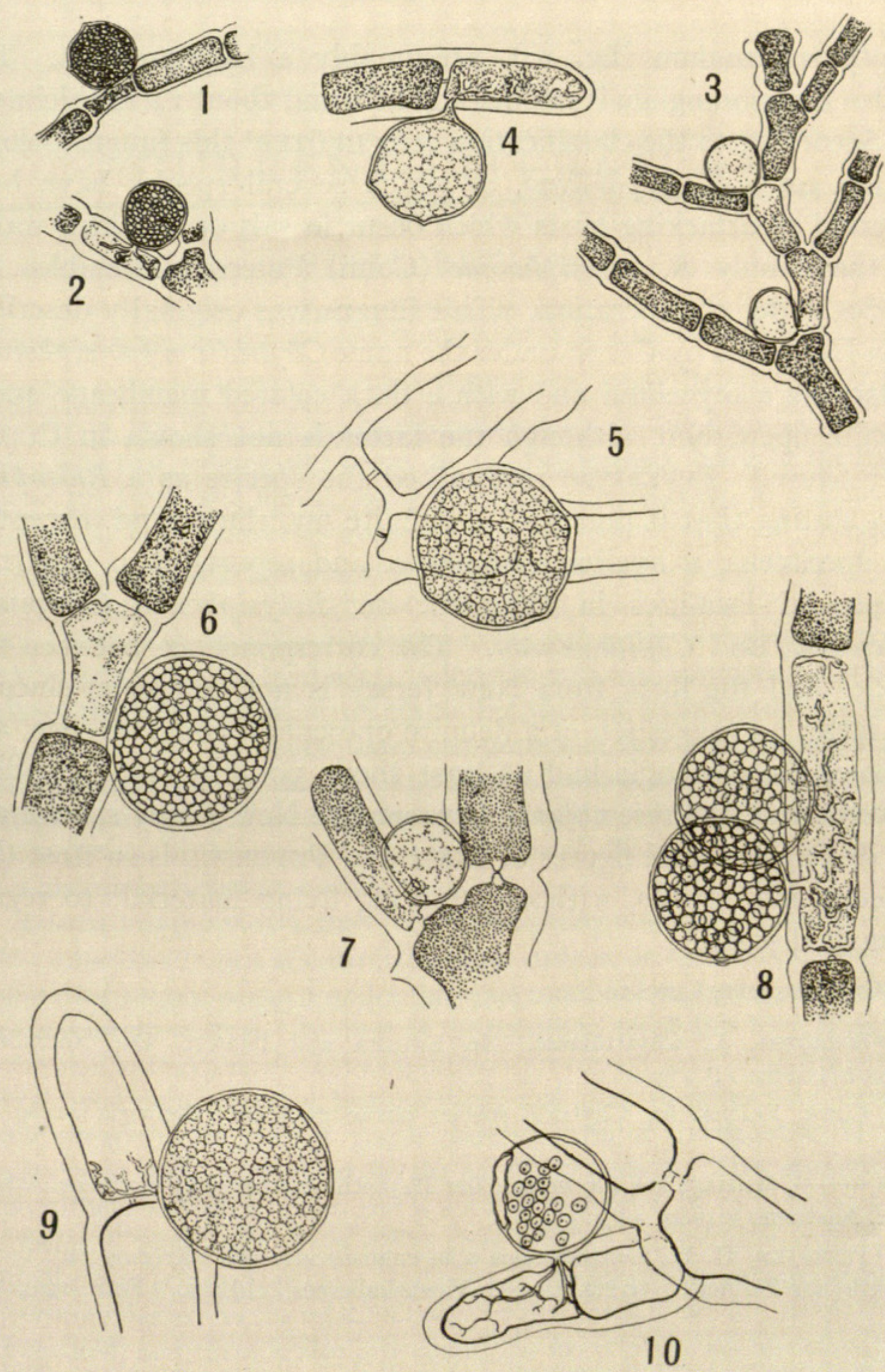

FIGS. I-Io.-Figs. I, 2, mature sporangia, one with two papillae, showing mycelium in host cell; fig. 3 , two immature sporangia showing exhaustion of host cells at end of which sporangia are attached; fig. 4 , immature sporangium with two papillae; fig. 5 , nearly mature sporangium from above, with three papillae (sporangium attached to basal cell of smaller branch); figs. 6, 9, mature sporangia, latter showing mycelium; fig. 7 , immature sporangium, showing rootlike base; fig. 8 , two mature sporangia on same host cell; fig. 10, nearly empty sporangium; spores with nuclei and blepharoplasts. Figs. $\mathrm{I}-3, \times_{480}$; figs. $4-\mathrm{IO}, \mathrm{X}_{\mathrm{1000}}$; all reduced to one-half in reproduction. 
empty sporangium (fig. ro), presumably a blepharoplast. The wall of the sporangium is smooth and firm and about I $\mu$ in thickness.

According to the classification of SCHRÖTER ${ }^{\mathrm{I}}$ this fungus belongs to the genus Rhizophidium, of which several species have been reported as attacking hosts which occur in salt or brackish water. Of these, only $R$. polysiphoniae (Cohn) Petersen resembles the species under consideration. This fungus was originally described from Helgoland by $\mathrm{CoHN}^{2}$ under the name Chytridium polysiphoniae, as lacking a mycelium and with a dark colored membrane and a definite operculum, although the latter is not shown in CoHN's later figure. ${ }^{3}$ PETERSEN $^{4}$ redescribed the species as a Rhizophidium, stating that it possessed a definite mycelium, and, except in old specimens, a hyaline membrane, and reports it as occurring in several localities in Denmark on Polysiphonia, Ceramium, Delessaria, and Callithamnion. The correspondence between this species and the form from New Jersey is not complete, since in the latter no suggestion of a definite operculum could be seen, and some of the sporangia had at least three, possibly more, papillae. Nevertheless, the resemblance between the New Jersey species and the descriptions and figures of CoHN and PETERSEN is so close that it seems inadvisable, without studying living material, to regard them as distinct.

\section{UNIVERSTTY OF CHICAGO}

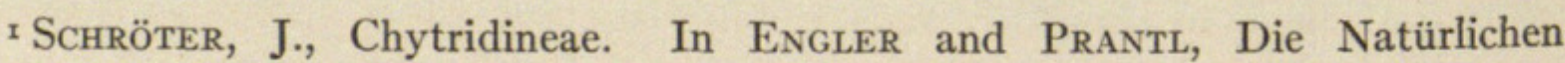
Pflanzenfamilien $\mathrm{I}:^{\mathrm{I}} \mathrm{I} 892$.

${ }^{2}$ Cohn, Ferdinand, Chytridii species novae marinae. Hedwigia 4:169-I70. 1865.

$3 \longrightarrow$, Beiträge zur Physiologie der Phycochromaceen und Florideen. Archiv Mikr. Anatomie 3:1-60. 1867 .

${ }_{4}^{4}$ Petersen, H. E., Contributions a la connaissance des Phycomycetes marins (Chytridinae Fischer). Overs. Danske Videnskabernes Selskabs. Forh. 1905:439488. 


\section{$2 \mathrm{BHL}$ Biodiversity Heritage Library}

Martin, G. W. 1922. "Rhizophidium Polysiphoniae in the United States." Botanical gazette 73(3), 236-238. https://doi.org/10.1086/332978.

View This Item Online: https://www.biodiversitylibrary.org/item/109575

DOI: https://doi.org/10.1086/332978

Permalink: https://www.biodiversitylibrary.org/partpdf/224338

\section{Holding Institution}

Missouri Botanical Garden, Peter H. Raven Library

\section{Sponsored by}

Missouri Botanical Garden

\section{Copyright \& Reuse}

Copyright Status: Public domain. The BHL considers that this work is no longer under copyright protection.

This document was created from content at the Biodiversity Heritage Library, the world's largest open access digital library for biodiversity literature and archives. Visit BHL at https://www.biodiversitylibrary.org. 